\title{
SPORTS AS A STEPPING-STONE FOR ENTREPRENEURSHIP: EXAMINING SPORTS UNIVERSITY STUDENTS
}

\author{
Marian Holienkaa, Jana Holienková2 ${ }^{2}$ Miroslav Holienka³
}

\begin{abstract}
${ }^{1}$ Department of Strategy and Entrepreneurship, Faculty of Management, Comenius University in Bratislava, Odbojárov 10, 82005 Bratislava, Slovak Republic

${ }^{2}$ Department of Psychology, Faculty of Arts, University of SS. Cyril and Methodius in Trnava, Nám. J. Herdu 2, 91701 Trnava, Slovak Republic

${ }^{3}$ Department of Sports Games, Faculty of Physical Education and Sports, Comenius University in Bratislava, Nábr. arm. gen. L. Svobodu 9, 81469 Bratislava, Slovak Republic
\end{abstract}

To cite this article: HOLIENKA MARIAN, HOLIENKOVÁ JANA, HOLIENKA MIROSLAV. 2018. Sports as a Stepping-Stone for Entrepreneurship: Examining Sports University Students. Acta Universitatis Agriculturae et Silviculturae Mendelianae Brunensis, 66(6): 1485-1496.

To link to this article: https://doi.org/10.11118/actaun201866061485

\begin{abstract}
Sports and entrepreneurship have several common attributes. Therefore, when focusing on entrepreneurship among university students, sports students deserve special attention. The main aim of our exploratory study was to examine personality traits, enterprising tendencies and entrepreneurial propensity of sports students. Our study was based on data gathered through own data collection using a survey instrument comprising of established measures of enterprising tendencies and interpersonal aspect of personality, and items capturing individual's entrepreneurial propensity and other personal and environmental attributes. We have collected 254 responses from 130 sports and 124 pedagogy students, who served as a comparison group. Our findings show that sports students exhibit higher enterprising tendency, significant differences in four out of eight examined general personality traits, and higher entrepreneurial propensity compared to their pedagogy counterparts. In search of potential origins of these differences and high embeddedness of entrepreneurship among sports students, we explored selected individual attributes as well as environmental factors related to respondents' personal and university settings. Based on our findings, we develop implications for entrepreneurship encouragement and utilization of enterprising potential in sports student population.
\end{abstract}

Keywords: entrepreneurship, students, sports, enterprising tendency, personality traits, education

\section{INTRODUCTION}

Sports and entrepreneurship have several common attributes. Therefore, when focusing on entrepreneurship in the population of university students, sports students deserve special attention. Attachment of sports students to entrepreneurship is driven by several pathways (logics, patterns etc.). First, sports students mostly choose their field of study due to inclination and future career orientation on sports, and sportsmen and sports professionals (such as coaches, physio specialists, managers etc.) often find themselves utilizing their enterprising self and acting as entrepreneurs (e.g. monitoring environment and estimating future actions, opportunity search and evaluation, acting on opportunities proactively etc.). This applies to "on-the-game" but also to "off-the-game" context. Thus, this is a good precondition to enhance their 
enterprising potential. Second, sportsmen and sports professionals often hold the responsibility for their professional development and performance in their own hands and are aligned with this mindset. They must know how to show their qualities and "sell" themselves. They frequently work on quasi-entrepreneurial basis, with different types of professional or freelancer contract. Third, involvement in sports and mainly in team sports naturally connects people and improves their networking capacity. The role of social capital in forming entrepreneurial propensity has been previously established (Ramos-Rodriguez, 2010), so strong and industry-relevant networks create favorable preconditions for getting involved in enterprising endeavors. Finally, a certain type of necessity plays a significant role as well. The career of professional sportsperson with attractive and financially rewarding lifestyle is only available to minority of elite sportsmen (Jones and Jones, 2014), and, also, options available to former professional sportsmen (elite or not) are rather limited. Thus, also after professional career, self-employment in sports-related activities seems as a feasible alternative. Following the above-mentioned arguments, the entrepreneurship potential among university sports students and future graduates is undoubted and need to equip them with competencies required to succeed in entrepreneurial career is obvious.

Many authors dealing with entrepreneurship among non-business disciplines student populations emphasize predominant focus of entrepreneurship research on business students as a justification for their focus. However, instead of using the shortage of supply as an argument, we believe that more important reason for such inquiry lies rather in the existence of a considerable demand. Besides specifics of sports context that we have described above, there is a general relevance of increased entrepreneurship learning and teaching in non-business disciplines (Nambisan, 2015). Enterprising mindset and entrepreneurial skills are becoming, due to the changing nature of business, employment and in fact the entire socio-economic environment, crucial for successful career and life path in various contexts not limited to traditional for-profit entrepreneurship, including employment, NGOs, cultural or community activities, research and academia, or public sector. Thus, developing an enterprising mindset and building entrepreneurial characteristics should be embedded in entire educational system, including all disciplines on the higher education level (Orbánová and Velichová, 2013). In addition to isolated efforts of increasing focus on entrepreneurship in particular disciplines, a cross-disciplinary approach connecting various domains is becoming especially important (Welsch, 2014). However, any effort to improve entrepreneurship encouragement of university students would benefit from reliable empirical evidence extracted from the relevant context of specific target population.
Furthermore, previous empirical studies have indicated that entrepreneurial propensities of university students across different fields of study vary (Sieger et al., 2016). Results of the Global University Entrepreneurial Spirit Students' Survey from Slovakia indicated that sports students are, besides students of science of art, the second most intensively involved in entrepreneurial activity (Holienka et al., 2018). Also, it has been found that entrepreneurial characteristics of students from various disciplines differ significantly (Holienka et al., 2015; Holienka and Holienková, 2014), while some studies on populations from other selected study fields also came to an opposite conclusion (Mesárošová and Mesároš, 2013). Thus, inquiries aimed at student populations from specific fields of study are needed to understand their specific context and act accordingly.

Therefore, to better understand whether and how sports serves as a potential stepping-stone to entrepreneurial path among university sports students, the main aim of our exploratory study was to examine personality traits, enterprising tendencies and entrepreneurial propensity of sports students. The main research question of the paper is as follows: Do sports students exhibit high enterprising tendency and entrepreneurial propensity?

The structure of the paper is conventional. The following section reviews literature on personality traits, enterprising tendency and entrepreneurial propensity. Section 3 describes data and methodology used in our study. Section 4 presents and discusses the findings while the last section provides a conclusion.

\section{Literature review}

In the following section we first review the literature dealing with personality traits and enterprising tendencies in their relation to individual entrepreneurial propensity. Then, we review the former empirical studies examining the entrepreneurship phenomenon and related issues in populations of sports university students.

\section{Personality, individual and environmental factors, enterprising tendency and entrepreneurial propensity}

Personality approach is one of the classical as well as one of the most controversial approaches to entrepreneurship (Rauch and Frese, 2012). In the earlier years of this approach, research was focused on identifying the great and heroic personality of an entrepreneur that would possess traits distinguishing the entrepreneurs from the remaining non-entrepreneur population. However, the findings usually led to ambiguous results as well as different conclusions whether such characteristics are born or learnt (Neck et al., 2014). One of the most influential criticizing works by Gartner (1988) argued that "Who is an entrepreneur?" was a wrong question. However, 
in recent years we have been witnessing a revival of personality approach with sounder theoretical background, reflection of potential mediating processes and situational contingencies, and increased methodological quality (Rauch and Frese, 2012). To provide more robust conceptualization of pathways through which individual differences are related to entrepreneurship, Rauch and Frese (2012) developed a model of entrepreneurs' personality characteristics and success (Fig. 1).

Personality traits in general are relevant individual attributes in relation to entrepreneurship, as they are defined by their propensity to act, being consistent across various situations, and being stable over time (Rauch and Frese, 2012). However, according to the presented model that follows the proximal/distant logic, there are two categories of personality traits that might be relevant for entrepreneurship: distant general or broad personality traits and more proximal specific personality traits. The broad traits are not assumed to be related to entrepreneurship outcomes directly, but rather through influencing more specific traits that affect goals and action strategies and, as a result, business creation and success. In addition, environmental factors play role in this interaction. Due to its generic focus, the model does not contain factors that are specific for student population.

Broad personality traits, as we have already mentioned above, should be less strongly related to entrepreneurship compared to more proximal specific traits. The reason is, according to Rauch and Frese (2012), that broad trait taxonomies are not directly linked to behaviors that are key for entrepreneurship. However, the authors also argue that meaningful relationships between some of the broad personality traits and entrepreneurship outcomes might be present, but their effect is mediated by specific traits and even more specific individual parameters such as goals and action strategies (see Fig. 1 above). This perspective is also supported by meta-analytical investigation. In his overview of five meta-analyses dealing with personality aspects of entrepreneurship,
Brandstätter (2011) found broad personality traits (in all cases conceptualized using the Big Five system) in predicting entrepreneurial intention and also entrepreneurs' performance. Accordingly, Rauch and Frese (2007) in their previous meta-analysis found general and broad personality traits significantly related to business success and business creation, even though this relationship was smaller compared to specific traits. In the specific context of Slovak student population, Flešková and Babiaková (2011) examined entrepreneurial intentions in relation to Big Five personality traits, finding no significant difference between students planning to start their own business and those favoring employment career. However, they found significant difference in four out of five personality traits (except of agreeableness) when dividing students according to self-confidence about having entrepreneurial skills.

Specific personality traits should be, unlike broad traits, related to specific concepts, one of them being entrepreneurship. They should be more proximal to specific behaviors and tasks of entrepreneurs (Baum and Locke, 2004). This is in line with findings of Leutner et al. (2014) who argue that narrow measure of entrepreneurial personality (in their case represented by META) predicts various forms of entrepreneurial outcomes more consistently compared to broad traits concepts. One of the works focused on determining specific personality traits relevant for entrepreneurship is that of Caird (1990, 1991, 1993) who developed a concept of enterprising tendency as well as its measure. According to Caird (1990), psychological attributes of entrepreneurs and enterprising people in general are common, with the only difference that entrepreneurs demonstrate them within the business enterprise context. In particular, the specific personality traits proposed by Caird as key components of enterprising tendency are: calculated risk-taking, creative tendency, high need for achievement, high need for autonomy, and an internal locus of control. First, calculated risk-taking is defined by Caird (1991) as the ability to

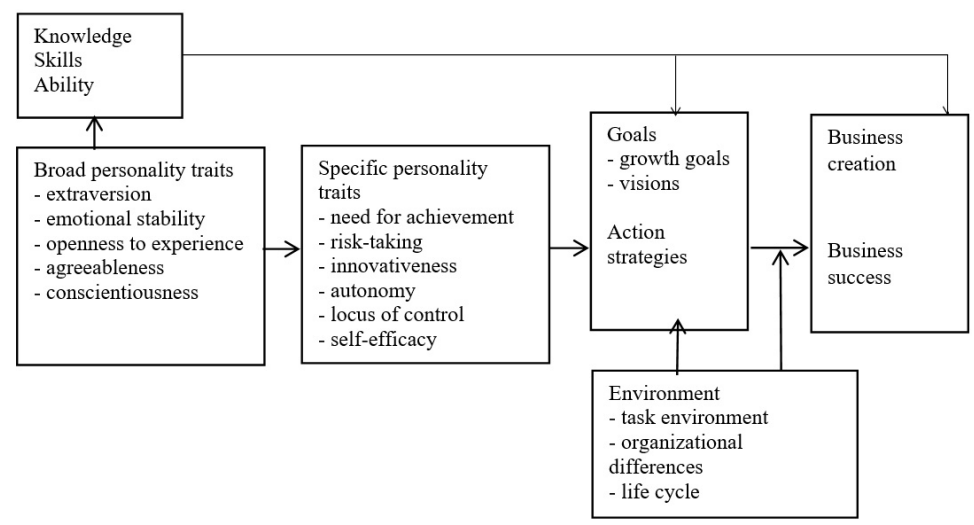

1: A model of entrepreneurs' personality characteristics and success Source: adapted from Rauch and Frese (2012) 
deal with incomplete information and act on a risky option, that requires skill, to analyze challenging but realistic goals. Even though risk-bearing is significantly typical for entrepreneurship, entrepreneurs can't be by no means considered as universal or extreme risk-takers. Contrary, they are rather risk-sensitive and carefully consider the risk with the attached reward to adopt either risk-avoidance or risk-taking behavior. Second, Caird (1991) defined creative tendency as the tendency to be imaginative, innovative, curious and versatile. Creativity is important for not only for innovative entrepreneurship, where it enhances ground-breaking high-potential innovation, but also for replicative entrepreneurs who utilize it to find ways to enter markets, produce their goods or services efficiently with limited resources and communicate with their customers. Third, need for achievement is linked with entrepreneurial motivation, which has a nature of achievement motivation rather than goal motivation (Caird, 1991). Individuals with high need for achievement take personal responsibility, constantly look for ways to improve and strive for feedback about their performance. Fourth, need for autonomy, which is related to several entrepreneurial attributes and often acts as an important motive to start a business, can be understood as the need to do and say as one likes despite conventional expectations (Caird, 1991). Entrepreneurs have to make independent decisions usually without any supervision, set their own goals, develop action plans and control goal achievement themselves. However, they often prefer being in control and avoiding restrictions and rules established by others (Rauch and Frese, 2012). Finally, the locus of control concept describes the extent to which individuals believe that their reinforcements are dependent upon their own behaviour, where internal locus of control means that one believes in controlling own destiny and future (Rotter, 1966). It is important for entrepreneurs as believing in one's own active influence helps to increase motivation to reach success (Rauch and Frese, 2012).

Besides the personality traits, certain role in affecting individual entrepreneurial propensity is attributed to environmental factors. In case of (not only) student populations, the most relevant drivers are entrepreneurship education and having parent entrepreneurs. In case of the first, the expected influence of exposure to entrepreneurship education is built on the concept of human capital (Becker, 1993) and mainly its entrepreneurship-specific dimension (Ramos-Rodriguez, 2010). Participation on entrepreneurship courses is supposed to equip students with characteristics and skills that make them more resourceful when facing business opportunities. Moreover, this effect might be further leveraged through exposure to entrepreneurial role models (Bosma et al., 2012) or increased entrepreneurship-specific self-efficacy (Arenius and Minniti, 2005). As for the latter, parent entrepreneurship is one of the most influential factors affecting student inclination towards entrepreneurship. The mechanism of its influence lies in post-birth factors, mainly in parental entrepreneurial role models (Sorensen, 2007; Lindquist et al., 2015). Being children of entrepreneur parents, students are supposed to gain realistic expectations about entrepreneurship (Chlosta et al., 2012), might observe and absorb entrepreneurship-related skills and behaviors through social learning (Bandura, 1986), and would often participate in various activities of their parents' business (Van Auken et al., 2006).

Finally, self-confidence about having required knowledge, skills and abilities required to start and run a business plays an important role in determining entrepreneurial propensity as well. Specifically, in the context of university students, we would be interested in the perceived effect of education on the level of entrepreneurial skills and qualities. If there is a positive perception, it should be transmitted to entrepreneurship propensity through the mechanisms of increased relevant human capital (Ramos-Rodriguez, 2010) and contextually-specific self-efficacy (Arenius and Minniti, 2005). In particular, if they will perceive that courses and subjects they attended resulted into increased entrepreneurship-specific human capital, they would be better equipped to spot or create entrepreneurial opportunities and act on them, and would be more confident about possessing required knowledge, skills and abilities.

In our study we follow the model proposed by Rauch and Frese (2012) and study broad personality traits as well as specific personality traits (also termed as enterprising tendencies) besides the entrepreneurial propensity among sports students. Moreover, we also examine the knowledge/skills/ability component of the model as well as environmental factors relevant to university students (i.e. exposure to entrepreneurial education and parent entrepreneurship).

\section{Sports students and entrepreneurship}

Relevance of entrepreneurship among sports students is reflected in academic literature, as it offers several empirical studies focused on sports university students in relation to entrepreneurship. The research questions examined include for example impact of entrepreneurship education on attitude towards an entrepreneurial career (Jones and Jones, 2014); relationship between various individual and environmental factors and entrepreneurial characteristics (Geri, 2013), entrepreneurial intentions (Gonzáles-Serrano et al., 2017, Gonzáles-Serrano et al., 2016; Hu and Ye, 2017) or entrepreneurial activity (Serarslan and Ozman, 2015). Also, considerable attention is paid to entrepreneurship education and training (Holmström et al., 2016; Ansari and Husin, 2015). While the above-mentioned studies examine situation in various countries, we found no 
academic study dealing with this population of students and entrepreneurship in Slovakia.

The results of empirical investigation shed some light on relationships and mechanisms between various factors, entrepreneurial intentions and entrepreneurial activity. For example, Jones and Jones (2014) found sports students to be enterprising by nature due to their prior experience in coaching or training within their disciplines. Accordingly, they found their high attraction to a future entrepreneurial career in sports-related field, mostly driven by existing potential entrepreneurial options together with limited alternative choices. Looking at individual factors related to entrepreneurial characteristics of sports students, Geri (2013) found several linkages, including relationship between gender and tolerance for ambiguity, or relationship between parent entrepreneur and innovativeness, tolerance for ambiguity and risk taking. Further, as for entrepreneurial intentions, Gonzáles-Serrano et al. (2017) suggest that the perceived entrepreneurial capacity to create an enterprise and the perceived entrepreneurial capacity to become an entrepreneur both significantly affect entrepreneurial intentions of sports science university students. In their previous study, Gonzáles-Serrano et al. (2016) found that while attitude towards entrepreneurship and the perceived behavior control worked as predictors of entrepreneurial intentions among sports students of both genders, subjective norms were found significant only among men. In addition, Hu and Ye (2017) found significant effects of entrepreneurial self-efficacy and alertness on entrepreneurial intention, and their findings also suggested influence of gender, previous entrepreneurial experience and exposure to entrepreneurship education. Finally, when investigating entrepreneurial activity and its drivers among sports management students, Serarslan and Ozman (2015) identified significant relation between entrepreneurial activity and age, family income and, quite surprisingly, having a business idea shared with no one else.

Building on the assumptions of natural attachment of sports students to enterprising, the literature concerning personality characteristics and entrepreneurial propensity, as well as on previous findings of empirical research derived from sports students' populations, we expect that sports students would exhibit higher enterprising tendency and propensity compared to students from other disciplines. This assumption serves as a guiding line throughout the next sections of the paper.

\section{MATERIALS AND METHODS}

In this section we describe methods and data employed in our exploratory study.

\section{Sample}

The sample of our quantitative study comprised of 254 university students (coming from two Slovak universities located in Bratislava and Trnava), out of that 130 students of physical education and sports, and 124 students of pedagogical disciplines from faculties of pedagogy and arts. The only sampling criterion applied was an active full-time study at undergraduate or graduate level, without any gender or age limitations. Our sample contained 122 female and 114 male respondents (18 respondents with missing indication of gender) with an average age of 21.76 years (minimum $=19$ years, maximum $=27$ years). All years of study on both undergraduate and graduate level were present in the sample. Participant were acquired during university courses using a convenience sampling method.

\section{Measure and variables}

Distant/general personality traits were measured using the Interpersonal diagnosis of personality questionnaire (Leary, T. et al., 1964, in: Kožený and Ganický, 1976) that attempts to create a scheme describing the interpersonal aspect of personality in specific circumstances, i.e. to create a classification system ofinterpersonal behavior. The aim of the survey instrument is to indicate the type and intensity of mechanisms that an individual uses in interaction with his/her interpersonal environment in order to secure himself/herself optimal conditions. The interpersonal behavior variables can be ordered around the two orthogonal polar dimensions: dominance-submission, hostility-affiliation. The personality typology is based on eight diagnostic categories yielded after pairing the two adjacent variables from the sixteen-variable rounded continuum: AP (managerial-autocratic), BC (competitive-narcissistic), DE (aggressive-sadistic), FG (rebellious-distrustful), HI (self-effacing-masochistic), JK (docile-dependent), LM (cooperative-overconventional) and NO (responsible-hypernormal). In our study we utilized the data aimed at identification of self-perception of own person and structure of individual's interpersonal world. The instrument was administered in standardized Slovak language version. The internal consistency analysis yielded excellent results (Cronbach's $\alpha=0.909$ ).

Specific personality traits were operationalized through the concept of general enterprising tendency and its attributes and measured using the General Enterprising Tendency v2 Test - GET2 test (Caird, 1991). GET2 test is a self-assessment scale comprising of 54 statements aiming to measure the key attributes of enterprising individuals: calculated risk taking (12 items), creative tendency (12 items), need for achievement (12 items), need for autonomy (6 items), and internal locus of control (12 items). The overall general enterprising tendency score computed as a total sum of all items, and the same logic is applied to calculate scores of particular attributes. We have translated the questionnaire following the requirements for survey instrument translation and distributed it in Slovak language version. The original instructions to administer and evaluate the survey instrument 
were followed. The internal consistency analysis of the questionnaire provided satisfactory values of Cronbach's alpha coefficient $(\alpha=0.723)$.

Measures of entrepreneurial propensity exposure to entrepreneurship education and perceived effect of education on the level of entrepreneurial skills and qualities were adopted from the Global University Entrepreneurial Spirit Students' Survey (GUESSS) questionnaire (Sieger et al., 2016), as the first author is involved in the GUESSS study as the head of national coordination team in Slovakia. The entrepreneurial propensity was examined using a single item where students indicated the relationship between "them and entrepreneurship" selecting from five potential levels: "currently running own business", "currently trying to start own business", "not in business, but would like to start after school", "not in business, but would like to start 5 years after school", and "not in business, don't plan to run own business in the future". We also further recoded this item into binary indicator of involvement in business with value 1 for the first two options, otherwise 0. Exposure to entrepreneurship education was measured using a single item where respondents indicated agreement with different statements about their experience with entrepreneurship-related courses as a part of their current study ("did not attend any course", "attended at least one elective course", "attended at least one compulsory course" or "studying a special program"), while we considered the highest level of exposure. Finally, perceived level of education was measured using five Likert-type scale items ( $1=$ not at all, $7=$ absolutely $)$ instructing respondents to indicate whether subjects and courses attended during their study contributed to increasing or improving the referred skills or qualities ("understanding of attitudes, values and motivations of entrepreneurs", "understanding the steps required to start a business", "managerial skills required to start a business", "networking skills" and "ability to identify opportunities").

\section{Method}

Data acquired through our questionnaire survey were evaluated using the IBM SPSS v.24 statistical package, employing the nonparametric tests (Mann-Whitney U test for comparison of two independent populations in values of continuous quantitative variables, Chi-Square test of independence for comparison of two independent population in values of categorical variables). The choice of methods was based on nonparametric nature of our data (values of coefficients for statistical indicators of data distribution - skewness and kurtosis - exhibited values $>1$ for all examined variables).

\section{RESULTS AND DISCUSSION}

Our exploration was aimed at identification of general enterprising tendency and its specific attributes, personality characteristics and entrepreneurial propensity of sports university students, as well as comparison of sports students with students of different field of study - pedagogical disciplines at faculties of arts and pedagogy.

In the first step of our exploratory analysis we aimed at examining differences in general personality traits between sports and pedagogy students. The results are displayed in Tab. I.

I: Comparison of personality traits between sports and pedagogy students

\begin{tabular}{|c|c|c|c|c|c|}
\hline & Field of study & $\mathbf{N}$ & Mean Rank & $\begin{array}{c}\text { Mann-Whitney } \\
\text { U test }\end{array}$ & Sig. (2-sided) \\
\hline \multirow{2}{*}{ Managerial - autocratic } & Sports & 130 & 147.12 & \multirow{2}{*}{5509.500} & \multirow{2}{*}{.000} \\
\hline & Pedagogy & 124 & 106.93 & & \\
\hline \multirow{2}{*}{ Competitive - narcissistic } & Sports & 130 & 149.24 & \multirow{2}{*}{5234.000} & \multirow{2}{*}{.000} \\
\hline & Pedagogy & 124 & 104.71 & & \\
\hline \multirow{2}{*}{ Aggressive - sadistic } & Sports & 130 & 141.05 & \multirow{2}{*}{6298.000} & \multirow{2}{*}{.002} \\
\hline & Pedagogy & 124 & 113.29 & & \\
\hline \multirow{2}{*}{ Rebellious - distrustful } & Sports & 130 & 136.25 & \multirow{2}{*}{6922.500} & \multirow{2}{*}{.051} \\
\hline & Pedagogy & 124 & 118.33 & & \\
\hline \multirow{2}{*}{ Self-effacing - masochistic } & Sports & 130 & 110.71 & \multirow{2}{*}{10242.500} & \multirow{2}{*}{.000} \\
\hline & Pedagogy & 124 & 145.10 & & \\
\hline \multirow{2}{*}{ Docile-dependent } & Sports & 130 & 132.57 & \multirow{2}{*}{7401.000} & \multirow{2}{*}{.256} \\
\hline & Pedagogy & 124 & 122.19 & & \\
\hline \multirow{2}{*}{ Cooperative - overconventional } & Sports & 130 & 135.23 & \multirow{2}{*}{7055.000} & \multirow{2}{*}{.084} \\
\hline & Pedagogy & 124 & 119.40 & & \\
\hline \multirow{2}{*}{ Responsible - hypernormal } & Sports & 130 & 134.07 & \multirow{2}{*}{7206.500} & \multirow{2}{*}{.142} \\
\hline & Pedagogy & 124 & 120.62 & & \\
\hline
\end{tabular}

Source: own elaboration 
As can be seen from Tab. I, only four of total eight examined personality dimensions exhibited statistically significant difference, namely managerial-autocratic $\quad(U=5509.500$; $\mathrm{p}=.000)$, competitive-narcissistic $(\mathrm{U}=5234.000$; $\mathrm{p}=.000), \quad$ aggressive-sadistic $\quad(\mathrm{U}=6298.000$; $\mathrm{p}=.002), \quad$ and self-effacing-masochistic $(\mathrm{U}=10242.500 ; \mathrm{p}=.000)$. Other personality dimensions (i.e. rebellious-distrustful, docile-dependent, cooperative-overconventional and responsible-hypernormal) did not achieve statistical significance in difference between the two examined populations (even though "rebellious-distrustful" dimension lies on the edge of statistical significance with $\mathrm{p}=.051$ ). Looking at mean values implies that sports students exhibited higher score compared to their pedagogy counterparts in "managerial-autocratic", "competitive-narcissistic" and "aggressive-sadistic" interpersonal dimensions, while they scored lower on "self-effacing-masochistic" dimension. This implies that sports students are characterized by energic competitive behavior, orientation on themselves (in terms of independence and self-confidence), by rough and vigorous approach to others, however adequate to particular social situation, by low level of manifested humility, shyness and ability to subordinate. With this respect, it is interesting that humiliated personality usually initiates assertiveness, aggressiveness and hostility of the others.
The second step of our exploration was aimed at analyzing the general enterprising tendency and its particular components - specific personality traits proximal to entrepreneurship. The measurement results indicated statistically significant differences in the overall level of enterprising tendency as well as in all analyzed GET2 test attributes (Tabs. II and III).

First, as displayed in Tab. II, we found $6.9 \%$ of sports students to have a high overall enterprising tendency (scoring 44 points and higher in the GET2test), while in pedagogy students' population there was no such individual. Also, $77.7 \%$ of sports students compared to $63.7 \%$ pedagogy students exhibited medium level of overall enterprising tendency (GET2 test score between 27 and 43 points). Moreover, while only $15.4 \%$ of sports students scored low in assessment of their overall enterprising tendency, proportion of low-enterprising individuals was $36.3 \%$ within pedagogy students sample. The results of Chi-Square test $(\chi 2=21.174, \quad p=.000) \quad$ confirm statistical significance of difference between the two examined populations.

Also, as we can see from the results presented in Tab. III, differences between sports and pedagogy students in overall enterprising tendency (in terms of the overall GET2 test score) were found to be significant according to the Mann-Whitney $U$ test results ( $U=4067.500$; $\mathrm{p}=.000)$. Thus, this result also indicates that sports and pedagogy students are different in their enterprising tendency, with higher levels of enterprising tendency exhibited by sports students.

II: Overall enterprising tendency levels of sports and pedagogy students

\begin{tabular}{ccccc}
\hline Factor & Values & Sports & Pedagogy & $\begin{array}{c}\text { Chi-square } \\
\text { (p-value) }\end{array}$ \\
\hline \multirow{2}{*}{ Overall enterprising tendency } & High & $6.9 \%$ & $0.0 \%$ & 21.174 \\
& Medium & $77.7 \%$ & $63.7 \%$ & $(.000)$ \\
\hline
\end{tabular}

Source: own elaboration

III: Comparison of enterprising tendency between sports and pedagogy students

\begin{tabular}{|c|c|c|c|c|c|}
\hline & Field of study & $\mathbf{N}$ & Mean Rank & $\begin{array}{c}\text { Mann-Whitney } \\
\text { U test }\end{array}$ & Sig. (2-sided) \\
\hline \multirow{2}{*}{ Need for achievement } & Sports & 130 & 143.33 & \multirow{2}{*}{6002.000} & \multirow{2}{*}{.000} \\
\hline & Pedagogy & 124 & 110.90 & & \\
\hline \multirow{2}{*}{ Calculated risk taking } & Sports & 130 & 157.01 & \multirow{2}{*}{4224.000} & \multirow{2}{*}{.000} \\
\hline & Pedagogy & 124 & 96.56 & & \\
\hline \multirow{2}{*}{ Need for autonomy } & Sports & 130 & 139.70 & \multirow{2}{*}{6474.000} & \multirow{2}{*}{.005} \\
\hline & Pedagogy & 124 & 114.71 & & \\
\hline \multirow{2}{*}{ Internal locus of control } & Sports & 130 & 146.15 & \multirow{2}{*}{5635.000} & \multirow{2}{*}{.000} \\
\hline & Pedagogy & 124 & 107.94 & & \\
\hline \multirow{2}{*}{ Creative tendency } & Sports & 130 & 147.44 & \multirow{2}{*}{5468.000} & \multirow{2}{*}{.000} \\
\hline & Pedagogy & 124 & 106.60 & & \\
\hline \multirow{2}{*}{ Overall enterprising tendency } & Sports & 130 & 158.21 & \multirow{2}{*}{4067.500} & \multirow{2}{*}{.000} \\
\hline & Pedagogy & 124 & 95.30 & & \\
\hline
\end{tabular}

Source: own elaboration 
As can be further seen in Tab. III, the differences in particular entrepreneurial characteristics between sports and pedagogy students measured using the Mann-Whitney U test reached the level of statistical significance in case of all of the examined characteristics, specifically, in need for achievement $(\mathrm{U}=6002.000 ; \quad \mathrm{p}=.000), \quad$ calculated risk-taking $(\mathrm{U}=4224.000 ; \mathrm{p}=.000)$, need for autonomy $(\mathrm{U}=6474.000 ; \mathrm{p}=.005)$, internal locus of control $(\mathrm{U}=5635.000 ; \mathrm{p}=.000)$, and creative tendency $(\mathrm{U}=5468.000 ; \mathrm{p}=.000)$. The closer look at mean rank further indicates that sports students achieved higher score compared to their pedagogy counterparts in all the examined characteristics. Thus, our findings suggest that sports students seem to be more willing to take calculated risk, more driven for achievement, less dependent from the others and environment around them, more creative and innovative, and having higher belief in own abilities.

In the third step of our analysis we focused on comparison of selected environmental factors, namely parent entrepreneurship and exposure to entrepreneurship education (Tab. IV), as well as perceived effect of education on entrepreneurial skills and qualities related to the construct of self-confidence about having required knowledge, skills and abilities (Tab. V).

From the results displayed in Tab. IV it's obvious that there was no statistically significant difference in the environmental factors between the examined sports and pedagogy students. Therefore, we might assume that either parent entrepreneurship or exposure to entrepreneurship education shall not explain the difference between sports and pedagogy students observed in the previous steps of our exploration.

Tab. V presents the results of exploration of differences between sports and pedagogy students in the perceived effect of received education on entrepreneurial skills and qualities. Three of the five examined variables achieved the significance level, namely perceived effect on understanding of attitudes, values and motivations of entrepreneurs $(\mathrm{U}=5164.500 ; \quad \mathrm{p}=.000)$, perceived effect on understanding the steps required to start a business $(\mathrm{U}=5651.500 ; \quad \mathrm{p}=.000)$, and perceived effect on managerial skills required to start a business $(\mathrm{U}=6144.000 ; \mathrm{p}=.004)$. Contrary, differences in perceived effect on networking skills ( $U=7177.000$; $\mathrm{p}=.258)$ and ability to identify opportunities $(\mathrm{U}=6860.000 ; \mathrm{p}=.090)$ did not achieve statistical significance. Detailed look at the Tab.V shows that sports students exhibit overall higher perceived effects in case of variables where they differ significantly from their pedagogy counterparts. Thus, we might hypothesize that the different level of enterprising tendency discovered in previous steps of our analysis could be caused by different effects of subjects and courses on development of entrepreneurial skills or qualities (whether objective or subjectively perceived). Pedagogy students do not believe that the educational activities experienced

IV: Comparison of environmental factors between sports and pedagogy students

\begin{tabular}{|c|c|c|c|c|}
\hline Factor & Values & Sports & Pedagogy & $\begin{array}{c}\text { Chi-square } \\
\text { (p-value) }\end{array}$ \\
\hline Parent entrepreneurship & Yes & $63,8 \%$ & $63.7 \%$ & $\begin{array}{l}0.001 \\
(.982)\end{array}$ \\
\hline \multirow{3}{*}{$\begin{array}{l}\text { Exposure to Entrepreneurship } \\
\text { education }\end{array}$} & No course & $44.2 \%$ & $50.0 \%$ & \multirow{3}{*}{$\begin{array}{l}1.707^{\mathrm{a}} \\
(.635)\end{array}$} \\
\hline & Elective & $11.6 \%$ & $12,9 \%$ & \\
\hline & Special program & $7.8 \%$ & $4.8 \%$ & \\
\hline
\end{tabular}

Source: own elaboration

V: Comparison of education effect on entrepreneurial skills and qualities between sports and pedagogy students

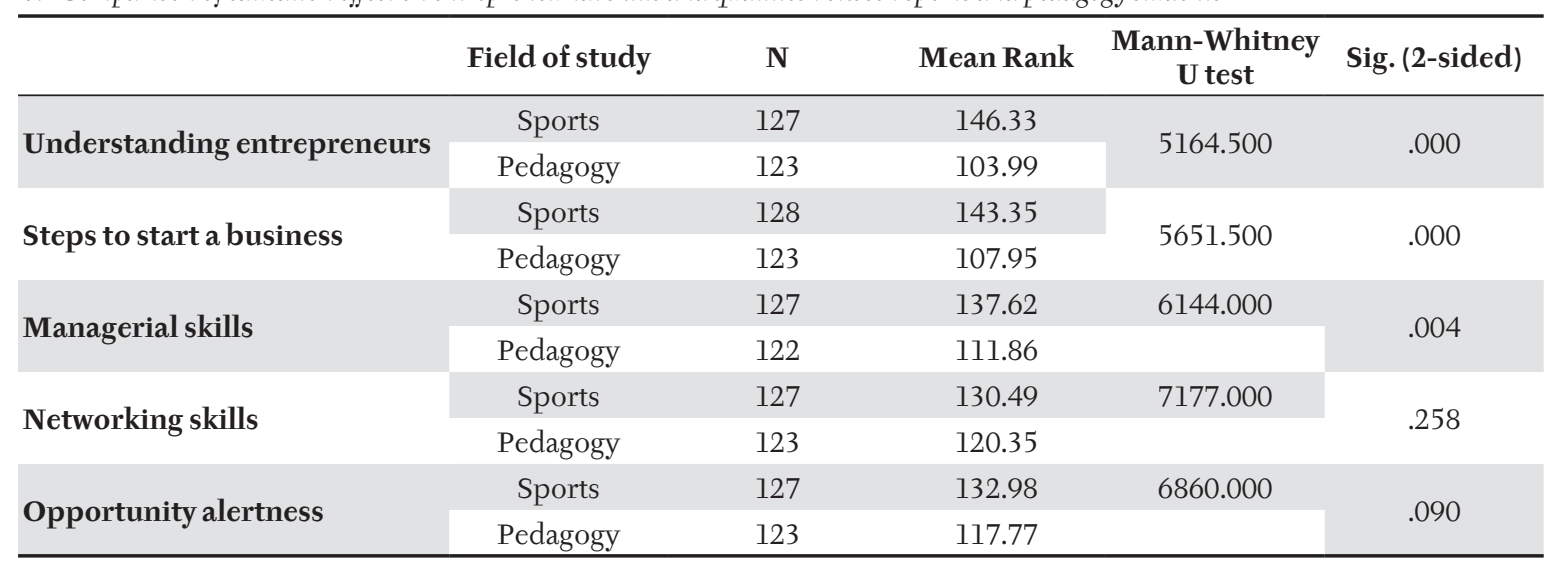

Source: own elaboration 
during their study considerably contributed to their understanding of attitudes, values and motivations of entrepreneurs, understanding the steps required to start a business, or managerial skills required to start a business.

The last step of our analysis was focused on exploration of entrepreneurial propensity of sports students and its comparison with pedagogy students. Our results (Tab. VI) indicate that there is a statistically significant difference between sports and pedagogy students in their entrepreneurial propensity $\left(\chi^{2}=33.742 ; \mathrm{p}=.000\right)$. The highest differences were observed in three categories of the entrepreneurial propensity, namely active involvement in entrepreneurship (10.1\% vs. $3.2 \%$ ), intention to start own business 5 years after school (48.1\% vs. $28.2 \%$ ), and no intention to have own business (12.4\% vs. $43.5 \%$ ). In other words, we found three times more active entrepreneurs and 1.7 times more future potential entrepreneurs among sport students compared to their pedagogy counterparts and, vice versa, 3.5 times less students with no interest in entrepreneurship path now or in the future. Also, as can be further seen in Tab. VI, a dichotomous perspective on entrepreneurial propensity (involved in active or nascent business vs. not involved in business) further confirms the statistically significant difference between the two examined groups of students $\left(\chi^{2}=4.535 ; p=.033\right)$. There are significantly more sports students involved in running an active business or actively attempting to start one, compared to pedagogy students. Accordingly, significantly more pedagogy students are not involved in business.

The results of different steps of our exploratory study bring us to several main findings. Most importantly, we hypothesize that entrepreneurship is considerably embedded within sports students. They exhibit higher enterprising tendency and only small part of them don't see entrepreneurship as a part of their current or future career, while several of them are already involved in some kind of entrepreneurial endeavors. In our opinion, the focus on sports as a part of lifestyle as well as the main element of a professional career provides substantial space for application and development of enterprising qualities.
Moreover, comparison of sports students with other group of non-business students (in our case pedagogy students) confirms significant differences, especially in entrepreneurship-relevant traits and entrepreneurship propensity, but also in some interpersonal dimensions of personality. Contrary, some of the most influential drivers of entrepreneurship involvement confirmed in theory and previous empirical research (such as parent entrepreneurship and entrepreneurial education and training) were found not to be different between the two studied groups. Also, controlling for potential effect of gender (another strong driver of entrepreneurship involvement) suggested its insignificant role in our samples (1. regression analysis did not prove gender as significant driver neither on the entire sample nor on separate study field samples, 2. despite fewer women in pedagogy sample, there were more female pedagogy student entrepreneurs compared to male). This further supports our hypothesis on special link between sports students and entrepreneurship, and implicit embeddedness of entrepreneurship in this part of student population. Therefore, it indicates special position of sports students in relation to entrepreneurship among the non-business fields of study.

Building on the above-mentioned findings, we argue that sports students are especially important target group when dealing with entrepreneurship encouragement in university environment (i.e. education, stimulation and incubation - based on Jansen et al., 2015), as there is both a need and an opportunity to leverage the existent high entrepreneurial potential. As our findings suggest, the quantity of entrepreneurship and enterprising potential is, by definition, present within this population. Therefore, the attention should be paid to waking up the latent entrepreneurs among the sports students, and mainly to improving preconditions so the quality of their business activity can develop as well. It would have a positive impact not only on individual lives of sports students themselves, but also on the entire society. This can be done especially through quality entrepreneurship education and training, both explicitly and by embedding its principles throughout the entire curriculum, through

VI: Entrepreneurial propensity of sports and pedagogy students

\begin{tabular}{|c|c|c|c|c|}
\hline Factor & Values & Sports & Pedagogy & Chi-square (p-value) \\
\hline \multirow{4}{*}{ Entrepreneurial propensity } & Active & $10.1 \%$ & $3.2 \%$ & \multirow{4}{*}{$\begin{array}{c}33.742 \\
(.000)\end{array}$} \\
\hline & Nascent & $10.1 \%$ & $7.3 \%$ & \\
\hline & Intention 5 years after school & $48.1 \%$ & $28.2 \%$ & \\
\hline & No intention & $12.4 \%$ & $43.5 \%$ & \\
\hline Entrepreneurial activity & No & $79.8 \%$ & $89.5 \%$ & $\begin{array}{l}4.535 \\
(.033)\end{array}$ \\
\hline
\end{tabular}

Source: own elaboration 
providing access to networking and role-models (thus supporting social learning), and through providing quality and individually-tailored support to those wishing to enter the entrepreneurial path or finding themselves in any stage of the entrepreneurship process.

\section{CONCLUSION}

Our findings show that sports students exhibit, compared to pedagogy students, significantly higher general enterprising tendency and all its five components (specific entrepreneurship-related personality traits). Moreover, we also observed significant differences in four out of eight examined general personality traits. Finally, sports students exhibit significantly higher entrepreneurial propensity compared to their pedagogy counterparts. Contrary, our investigation of environmental factors had not discover any differences between the two groups, suggesting that the distinctive character of enterprising tendency and entrepreneurial propensity of sports students is of a rather intrinsic nature. There is a sound evidence from former empirical studies and theory background that supports the findings of our exploration among Slovak university student population. We hypothesize that sports students have by definition a special relation to entrepreneurship, and due to quite many similarities in fundamental nature of the two, sports represents a good stepping-stone for entrepreneurship.

Our results contribute to the existing body of knowledge among researchers and practitioners in several ways. First, our exploratory study fills the gap in researching sports students in relation to entrepreneurship that exists (not only) locally in our university environment. There have been several studies aimed at sports students, however, it's an just increment compared to research on business students. Also, no study was found in our regional context, where attention to student entrepreneurship in non-business fields of study is still rather low. Second, our findings justify for the relevance of entrepreneurship encouragement among sports students, by building on theory background and providing arguments extracted from empirical exploration. Entrepreneurship education programmers and practitioners have elementary overview of the situation, and solid arguments in their hands to further develop entrepreneurship encouragement initiatives among students in this field of study. Third, we also provide undisputable arguments for further inquiry in this direction of research. Finally, in terms of methodology applied, analysis of interpersonal dimensions of personality in relation to entrepreneurship is quite unique, as most former studies dealing with broad personality traits relied on five-factor model of personality (Rauch and Frese, 2012; Brandstätter, 2011) or, in fewer cases, on Cattell's or Eysenck's theories (Jarvis, 2006). However, interpersonal interaction is strongly linked with entrepreneurship, thus, in our opinion, this method opens a valuable perspective on personality-entrepreneurship outcome relation.

\section{Acknowledgements}

This work was supported by the Slovak Research and Development Agency under the contract No. APVV-14-0647.

\section{REFERENCES}

ANSARI, P. and HUSIN, S. 2015. Entrepreneurship Education in Sports: Issues and Challenges. In: Proceedings of $4^{\text {th }}$ International Conference on Management, Finance $\sigma$ Entrepreneurship (ICMFE-2015). International Foundation for Research and Development, 11-12 April. Medan, Indonesia: IFRD, pp. 60-66.

ARENIUS, P. and MINNITI, M. 2005. Perceptual Variables and Nascent Entrepreneurship. Small Business Economics, 24(3): 233-247.

BANDURA, A. 1986. Social foundations of thought and action: A social cognitive theory. Englewood Cliffs, NJ: Prentice-Hall.

BAUM, J. R. and LOCKE, E. A. 2004. The relation of entrepreneurial traits, skill, and motivation to subsequent venture growth. Journal of Applied Psychology, 89(4): 587-598.

BECKER, G. S. 1993 Human Capital: A Theoretical and Empirical Analysis with Special Reference to Education. $3^{\text {rd }}$ Edition. Chicago and London: University of Chicago Press.

BOSMA, N. et al. 2012. Entrepreneurship and role models. Journal of Economic Psychology, 33(2): 410-424.

BRANDSTÄTTER, H. 2011. Personality aspects of entrepreneurship: A look at five meta-analyses. Personality and Individual Differences, 51(3): 222-230.

CAIRD, S. 1990. What Does it Mean to be Enterprising? British Journal of Management, 1(3): 137-145.

CAIRD, S. 1991. Testing Enterprising Tendency in Occupational Groups. British Journal of Management, 2(4): 177-186.

CAIRD, S. 1993. What do psychological tests suggest about entrepreneurs? Journal of Managerial Psychology, 8(6): 11-20. 
FLEŠKOVÁ, M. and BABIAKOVÁ, B. 201l. Entrepreneurship in relation to Big Five personality dimensions [in Slovak: Podnikanie vo vztahu k osobnostným dimenziám Big Five]. In: Sociálne procesy a osobnost 2010: zborník príspevkov. Stará Lesná, 20-22 September. Košice: Spoločenskovedný ústav SAV, pp. 100-107.

GARTNER, W. B. 1988. Who is an Entrepreneur? is the wrong question. American Journal of Small Business, 12(4): 11-32.

GERI, S. 2013. Research on Entrepreneurial Characteristics of Students in School of Physical Education and Sports. Turkish Journal of Education, 2(3): 50-60.

GONZÁLEZ-SERRANO, M. H. et al. 2016. The influence of gender and academic training in the entrepreneurial intention of physical activity and sport sciences students [in Spanish: La influencia del género y de la formación académica en la intención de emprender de los estudiantes de ciencias de la actividad física y el deporte]. Intangible Capital, 12(3): 759-788.

GONZÁLEZ-SERRANO, M. H. et al. 2017. The importance of developing the entrepreneurial capacities in sport sciences university students. International Journal of Sport Policy and Politics, 9(4): 625-640.

HOLIENKA M., HOLIENKOVÁ J. and GÁL P. 2015. Entrepreneurial Characteristics of Students in Different Fields of Study: a View from Entrepreneurship Education Perspective. Acta Univ. Agric. Silvic. Mendelianae Brun., 63(6): 1879-1889.

HOLIENKA, M. and HOLIENKOVÁ, J. 2014. Enterprising tendencies of management and psychology students: differences and common attributes. Comenius Management Review, 8(1):39-52.

HOLIENKA, M., GÁL, P. and PILKOVÁ, A. 2018. Slovak students and entrepreneurship. GUESSS 2016 [in Slovak: Slovenskí študenti a podnikanie. GUESSS 2016]. Bratislava: Comenius University in Bratislava. In print.

HOLMSTRÖM, S., LINDBERG, E. and JANSSON, J. 2016. Entrepreneurial Education Embedded in Sport Psychology: A Swedish Case Study. Journal of Education and Training, 3(1): 126-138.

HU, R. and YE, Y. 2017. Do Entrepreneurial Alertness and Self-efficacy Predict Chinese Sports Major Students' Entrepreneurial Intention? Social Behavior and Personality, 45(7): 1187-1196.

CHLOSTA, S. et al. 2012. Parental role models and the decision to become self-employed: The moderating effect of personality. Small Business Economy, 38: 121-138.

JANSEN, S. et al. 2015. How education, stimulation, and incubation encourage student entrepreneurship: Observations from MIT, IIIT, and Utrecht University. The International Journal of Management Education, 13(2): 170-181.

JARVIS, M. 2006. Sport psychology: a student's handbook. Hove, East Sussex: Routledge.

JONES, P. and JONES, A. 2014. Attitudes of Sports Development and Sports Management undergraduate students towards entrepreneurship. Education + Training, 56(8/9): 716-732.

KOŽENÝ, J. and GANICKÝ, P. 1976. Interpersonal diagnosis of personality questionnaire [in Czech: Dotazník interpersonální diagnózy - ICL]. Bratislava: Psychodiagnostické a didaktické testy.

LEUTNER, F. et al. 2014. The relationship between the entrepreneurial personality and the Big Five personality traits. Personality and Individual Differences, 63: 58-63.

LINDQUIST, M., SOL, J. and VAN PRAAG, M. 2015. Why Do Entrepreneurial Parents Have Entrepreneurial Children? Journal of Labor Economics, 33(2): 269-296

MESÁROŠOVÁ, M. and MESÁROŠ, P. 2013. Enterprising tendency of students and entrepreneurs [in Slovak: Podnikatel'ská tendencia študentov a podnikatel'ov]. In: Psychológia práce a organizácie 2012: zborník z medzinárodnej konferencie. UPJŠ, 23-24 April. Košice: UPJŠ, 89-101.

NAMBISAN, S. 2015. Embracing Entrepreneurship Across Disciplines. Cheltenham: Edward Elgar, 2015.

NECK, H. et al. 2014. Teaching Entrepreneurship. A Practice-Based Approach. Cheltenham: Edward Elgar.

ORBÁNOVÁ, D. and VELICHOVÁ, L. 2013. Importance of Entrepreneurship and Financial Literacy in the Socio-Economic Progress and Personal Growth of Young People in the Slovak Republic [in Slovak: Význam podnikavosti a finančnej gramotnosti v socioekonomickom a osobnom rozvoji mladých l'udí v Slovenskej republike]. Sociológia, 45(5): 470-488.

RAMOS-RODRIGUEZ, R. A. et al. 2010. What you know or who you know? The role of intellectual and social capital in opportunity recognition. International Small Business Journal, 28(6): 566-582.

RAUCH, A. and FRESE, M. 2007. Let's put the person back into entrepreneurship research: A meta-analysis on the relationship between business owners' personality traits, business creation, and success. European Journal of Work and Organizational Psychology, 16(4): 353-385.

RAUCH, A. and FRESE, M. 2012. Born to Be an Entrepreneur? Revisiting the Personality Approach to Entrepreneurship. In: BAUM, J. R. et al. (Eds.). The Psychology of Entrepreneurship. New York, NY: Psychology Press.

ROTTER, J. B. 1966. Generalized expectancies for internal versus external control of reinforcement. Psychological Monographs, 80(1): 1-28.

SERARSLAN, M. Z. and OZMAN, C. 2015. Investigation of entrepreneurship levels of university students studying at sports management departments in terms of some variables. Journal of Health, Sport and Tourism, 6(1): 50-55.

SIEGER, P., FUEGLISTALLER, U. and ZELLWEGER, T. 2016. Student Entrepreneurship 2016: Insights From 50 Countries. St. Gallen/Bern: KMU-HSG/IMU. 
SORENSEN, J. B. 2007. Closure and exposure: Mechanisms in the intergenerational transmission of self-employment. Research in the Sociology of Organizations, 25(83): 83-124.

VANAUKEN, H.etal.2006. The influence of rolemodels on entrepreneurial intentions. Journalof Developmental Engineering, 11(2): 157-167.

WELSCH, D. H. B. 2014. Creative Cross-Disciplinary Entrepreneurship. New York: Palgrave Macmillan.

Marian Holienka: marian.holienka@fm.uniba.sk

Jana Holienková: jana.holienkova@ucm.sk

Miroslav Holienka: holienka@fsport.uniba.sk 